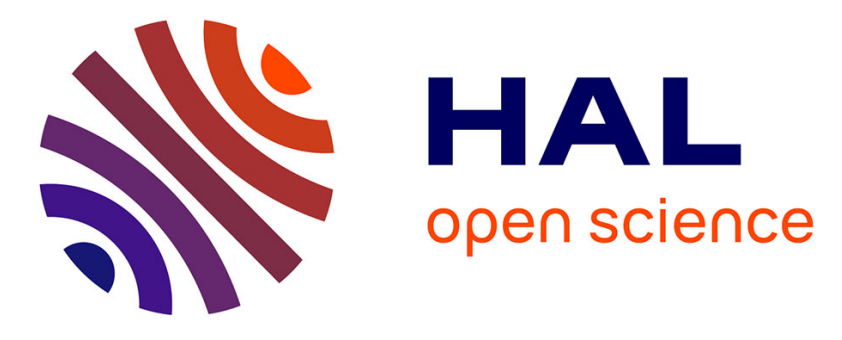

\title{
Organic acids and thymol: unsuitable for alternative control of Aethina tumida (Coleoptera: Nitidulidae)?
}

Sven Buchholz, Katharina Merkel, Sebastian Spiewok, Anton Imdorf, Jeffery

Pettis, David Westervelt, Wolfgang Ritter, Michael Duncan, Peter

Rosenkranz, Robert Spooner-Hart, et al.

\section{To cite this version:}

Sven Buchholz, Katharina Merkel, Sebastian Spiewok, Anton Imdorf, Jeffery Pettis, et al.. Organic acids and thymol: unsuitable for alternative control of Aethina tumida (Coleoptera: Nitidulidae)? Apidologie, 2011, 42 (3), pp.349-363. 10.1007/s13592-011-0021-0 . hal-01003552

\section{HAL Id: hal-01003552 https://hal.science/hal-01003552}

Submitted on 1 Jan 2011

HAL is a multi-disciplinary open access archive for the deposit and dissemination of scientific research documents, whether they are published or not. The documents may come from teaching and research institutions in France or abroad, or from public or private research centers.
L'archive ouverte pluridisciplinaire HAL, est destinée au dépôt et à la diffusion de documents scientifiques de niveau recherche, publiés ou non, émanant des établissements d'enseignement et de recherche français ou étrangers, des laboratoires publics ou privés. 


\title{
Organic acids and thymol: unsuitable for alternative control of Aethina tumida (Coleoptera: Nitidulidae)?
}

\author{
Sven Buchholz ${ }^{1}$, Katharina Merkel ${ }^{2}$, Sebastian SpiewoK ${ }^{3}$, Anton Imdorf ${ }^{1}$, \\ Jeffery S. Pettis ${ }^{4}$, David Westervelt ${ }^{5}$, Wolfgang Ritter ${ }^{6}$, Michael Duncan ${ }^{7}$, \\ Peter RosenKranz ${ }^{8}$, Robert SpoOnER-HART ${ }^{7}$, Peter NEUMANN ${ }^{1,9}$

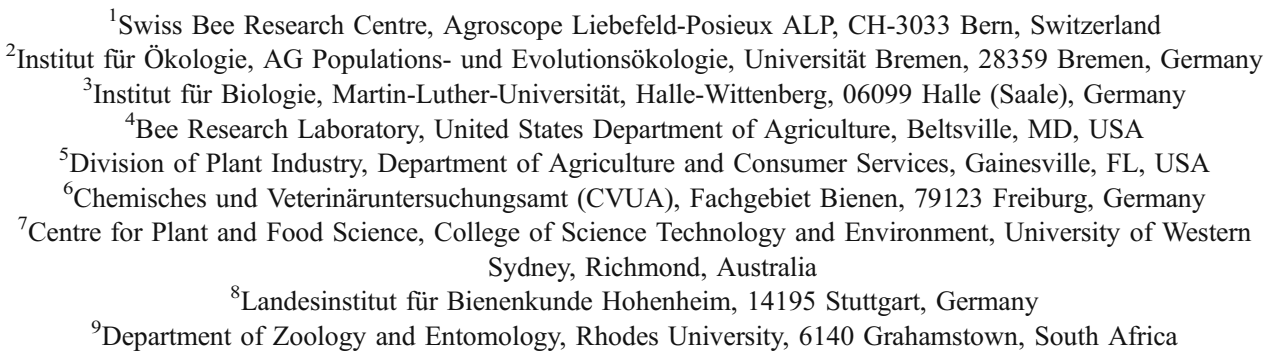

Received 4 February 2010 - Revised 25 May 2010 - Accepted 23 June 2010

\begin{abstract}
To explore alternative strategies to synthetic insecticides for control of Aethina tumida, the small hive beetle (SHB), treatments already established against two other honeybee pests, Varroa destructor and Galleria mellonella, were investigated. In the laboratory, eggs, larvae, and adults of SHB were treated with thymol $(10,20$, and $50 \mathrm{mg})$ or with organic acids: $85 \%$ formic acid $(0.125,0.25,0.5,0.75,1.0$, and $2.0 \mathrm{~mL})$, $15 \%$ lactic acid $(0.5,1.0,1.5$, and $2.0 \mathrm{~mL}$ ), oxalic acid (dihydrate crystals $35 \mathrm{~g} / \mathrm{L} ; 0.25,0.5,0.75,1.0$, and $2.0 \mathrm{~mL}$ ), and $65 \%$ acetic acid $(0.5,1.0,1.5$, and $2.0 \mathrm{~mL})$. Some of the chosen concentrations of formic and oxalic acid resulted in high mortalities of all SHB life stages. Therefore, they were further evaluated in the field utilising standard methods for control of $V$. destructor in Europe. After exposure to evaporating formic acid $\left(85 \%\right.$, Nassenheider $\left.{ }^{\circledR}\right)$ and oxalic acid ( 2 g dehydrate crystals, Varrox $\left.{ }^{\circledR}\right)$, mortality in all SHB tested stages did not increase significantly. The same was true for trials with $85 \%$ (adults) or $60 \%$ (eggs and larvae) formic acid, evaporating from sponge tissues in diagnostic trays. In fact, some SHBs used the diagnostic trays to hide or oviposit. Despite treating extracted honey combs with $65 \%$ acetic acid, SHBs still reproduced on the combs' pollen cells. In conclusion, none of the tested methods can be recommended to control SHBs.
\end{abstract}

Apis mellifera / formic acid / lactic acid / oxalic acid / pest management / small hive beetle

\section{INTRODUCTION}

The most serious threats to European derived honeybees, Apis mellifera L., are invasive parasites such as varroa mites (Varroa destructor Anderson and Trueman) and tracheal mites

Corresponding author: S. Buchholz, buchholz.sven.berlin@gmx.de Manuscript editor: David Tarpy
(Acarapis woodi Rennie) and, more recently, small hive beetles (SHBs), Aethina tumida Murray. Adult SHBs feed and reproduce in honeybee colonies in Africa (Lundie 1940; Neumann and Elzen 2004) and cause considerable economic damage to apiculture operations in the USA (Hood 2004) and Australia (Gillespie et al. 2003; Spiewok et al. 2007).

SHB infested colonies in the USA have been treated with the insecticide CheckMite+ ${ }^{\mathrm{TM}}$ con- 
taining coumaphos (Elzen et al. 1999; Hood 2000) with varying degrees of success (Mostafa and Williams 2002; Ellis 2005a). In many regions worldwide, varroa populations are already resistant to this agent (Spreafico et al. 2001; Elzen and Westervelt 2002; Pettis 2003). With resistance, pest control requires increasing doses of the active substance to be effective, resulting in another drawback of chemical control - the accumulation of residues in the bee products (Bogdanov et al. 1998; Wallner 1999; Kochansky et al. 2001). Several strategies using alternatives to synthetic insecticides for control of SHB (e.g., Hood 2004; Ellis 2005a, b) have been developed. In-hive traps mounted on frames and filled with liquid compounds (mineral oil, cider vinegar, beer, ethylene glycol, alcohol, and honey) were tested by Hood and Miller (2003) to attract and/or kill adult beetles. Selected entomopathogenic fungi (Ellis et al. 2004; Mürrle et al. 2006) and nematode species (Cabanillas and Elzen 2006; Ellis et al. 2010) were detected, and their potential as biological control organisms was assessed.

Several attempts have also been made to control SHBs and other pests simultaneously. Empty combs have been sprayed with suspensions of spores of Bacillus thuringiensis Berliner (B $401{ }^{\circledR}$ ), a method used to control greater wax moth, Galleria mellonella L., in an attempt to control SHB reproduction (Buchholz et al. 2006). The application of organic acids or thymol, the essential oil of Thymus vulgaris L., can reduce infestation levels by $V$. destructor (Imdorf and Kilchenmann 1990; Rademacher et al. 1999; Imdorf et al. 1999; Mutinelli and Baggio 2004; Rademacher and Harz 2006). Ellis and Delaplane (2006) assessed effects of the varroa treatment Apilife $\operatorname{Var}^{\mathrm{TM}}$, which includes thymol, on host-seeking behaviour of adult SHBs. Schäfer et al. (2009) evaporated organic acids in nucleus boxes and showed success in reducing numbers of adults with acetic acid and beetle reproduction with formic acid. In storage rooms and honey houses, $G$. mellonella has been successfully controlled with acetic acid (Moosbeckhofer 1993). Lundie
(1940) suggested that stored combs could be fumigated with carbon bisulphide to prevent infestation by SHB, and Mostafa and Williams (2002) showed that paradichlorobenzene kept beetles away from stored combs, along with wax moths. As both substances are chemicals, resistance and residue problems will likely arise with increased usage.

With the aim of controlling bee pests simultaneously, our objectives were to: (1) screen a wide range of substances against bee pests (organic acids and thymol) in different concentrations in the laboratory to single out their potential for the control of SHB, (2) test the most promising substances in live colonies under field conditions, and (3) test acetic acid as a potential SHB control on stored and extracted honey combs. We expected that the test substances might serve as suitable substitutes for conventional chemical controls of SHBs within bee colonies, storage rooms, or both.

\section{MATERIALS AND METHODS}

\subsection{Laboratory experiments}

The experiments were conducted at Rhodes University, Grahamstown, South Africa, in an environmental chamber at $30 \pm 1{ }^{\circ} \mathrm{C}$ in permanent darkness. Beetles used for experiments were obtained from a colony reared in the laboratory (Mürrle and Neumann 2004).

\subsubsection{Treatments of SHBs with organic acids and thymol}

Three different life stages of SHB were treated using 25 eggs, larvae, or adults per replicate in $600-\mathrm{ml}$ glass beakers. Cohorts of unsexed, 10- to 20-day-old adult SHBs were provided with $5.0 \mathrm{~mL}$ $\mathrm{H}_{2} \mathrm{O}$ on a wick (pulp paper, Weiland, Dahlwitz Hoppegarten, Germany) and with $\sim 1.0 \mathrm{~cm}^{3}$ cube of icing sugar mixed with honey $(2: 1)$ to prevent dehydration and cannibalism. Wandering larvae were also tested, as they sometimes gather on the bottom board before leaving the hive to pupate (Hood 2004), thereby exposing themselves to treatment agents. The 
wandering larvae (aged 10-14 days) were sprinkled with $2.0 \mathrm{~mL} \mathrm{H}_{2} \mathrm{O}$ per beaker to avoid dehydration (Schmolke 1974). No food was provided because "mature" SHB larvae no longer feed (Lundie 1940). Eggs were collected 1 day prior to commencing the experiment by providing SHB oviposition sites (Hoffmann et al. 2008) in rearing boxes with $\sim 200$ adult beetles for a period of $8 \mathrm{~h}$ to obtain eggs of known age. A total of 25 eggs were transferred with a single-hair brush onto a 5-mm-thick slice of a grape berry and placed in a glass Petri dish (diameter= $6.0 \mathrm{~mm}$ ). Each dish was then transferred into a beaker. On the fruit slices, the eggs were unlikely to desiccate, and the hatching larvae were provided with food and moisture (Eischen et al. 1999; Ellis et al. 2002; Buchholz et al. 2008). All beakers were covered with nylon gauze to prevent SHB escape and facilitate gas exchange. One beaker was placed in each corner of a glass box $[360 \times 360 \times 360 \mathrm{~mm}]$ (Figure 1).

Formic acid, acetic acid, and thymol were applied separately as evaporation treatments (Moosbeckhofer 1993; Rademacher et al. 1999; Imdorf et al. 1999). The portions of $85 \%$ formic acid $(0.125,0.25,0.5$, $0.75,1.0$, and $2.0 \mathrm{~mL})$ or $65 \%$ acetic acid $(0.5,1.0$, 1.5 , and $2.0 \mathrm{~mL}$ ) were each pipetted onto a wick [ $5 \times$
$6 \mathrm{~cm}$ ] on a glass Petri dish, which was set in the centre of the glass box bottom. Thymol crystals (10, 20, and $50 \mathrm{mg}$; 99\%) were placed on Petri dishes without wicks. One trial with $1.0 \mathrm{~mL}$ water on a wick served as control for the evaporation assays.

Solutions of $15 \%$ lactic acid $(0.5,1.0,1.5$, and $2.0 \mathrm{~mL})$ and oxalic acid $(0.25,0.5,0.75,1.0$, and $2.0 \mathrm{~mL}$; made from oxalic acid dihydrate crystals, $35 \mathrm{~g} / \mathrm{L}$ ) were dripped with a syringe directly onto the individuals in the beakers as contact agents. For the respective controls, $1.0 \mathrm{~mL}$ water was used per beaker.

The glass boxes were closed tightly with a glass lid. Ventilators (CY206 Sunon ${ }^{\circledR}$, Elektronica-Online, Schinveld, Netherlands) installed in the centres of each inner lid side facilitated equal distribution of the volatiles within the boxes. For reasons of consistency, the same ventilators were also used in the treatments with contact agents and in all respective controls.

For SHB larvae and adults, six replicate beakers were conducted for each concentration and substance. For eggs, however, eight replicates were used because preliminary investigations showed a high variance in egg mortality, even in control treatments. After $6,12,24$, and $48 \mathrm{~h}$, the beakers were briefly removed from the glass boxes to record larval and

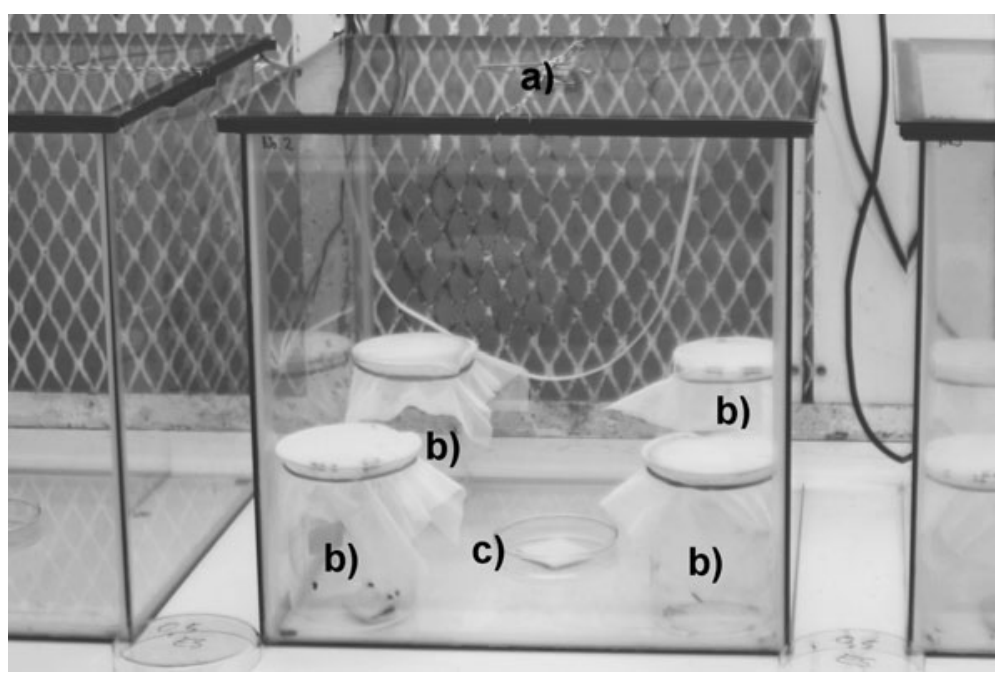

Figure 1. Experimental design to apply organic acids and thymol to different SHB life stages in the laboratory. $a$, ventilator under the lid of the glass box; $b$, beakers containing either eggs, larvae, or adult SHBs covered with nylon gauze; $c$, Petri dish with volatile on pulp paper wick, not applied when contact agents were used. 
adult mortality as well as numbers of hatched eggs. None of the dead larvae or adults were removed. In contrast, newly emerged larvae were removed to prevent cannibalism. After $72 \mathrm{~h}$, the experiment was terminated and mortality was assessed for adults and larvae, and the numbers of hatched eggs were counted.

The quantification of the volatiles (formic and acetic acid as well as thymol) used in the glass box atmospheres was conducted at the Swiss Bee Research Centre. Air samples were taken (Leichnitz 1985) after 6, 24, 48, and $72 \mathrm{~h}$ using an identical experimental setup (Imdorf 2005) but without any SHBs. They were analysed with a gas chromatograph using standard procedures (Imdorf et al. 1995).

\subsubsection{Treatments of SHBs with formic and oxalic acid for 8 days}

Larval and young adult SHBs were exposed to formic and oxalic acid for 8 days to investigate the agents' potential effects on oviposition and metamorphosis. Two days prior to the experiment, newly emerged adults were sexed according to Schmolke (1974), and genders were kept on a water diet in separate containers to avoid mating. For each replicate, 20 male or female beetles were transferred onto filter paper placed in a glass beaker $(600 \mathrm{~mL})$. The beetles were provided with $5 \mathrm{~g}$ pollen and $5.0 \mathrm{~mL}$ water, and then the beakers were closed with nylon gauze. One hundred young larvae ( $<48 \mathrm{~h}$ old) were collected from rearing boxes and distributed equally into four beakers equipped with pollen and water. To observe possible long-term effects, sublethal doses of $85 \%$ formic acid $(0.25 \mathrm{~mL})$ and oxalic acid $(0.5 \mathrm{~mL}, 35 \mathrm{~g} / \mathrm{L})$ were chosen from the experiment above (Sect. 2.1.1) and applied in the same way. Water and pollen were added after 2, 4, and 6 days, if required. After 8 days, the treatment was terminated, and live individuals were sampled for the second part of the experiment. For both applications and life stages, respective controls with the same amounts of water were performed. After the treatment, female and male beetles were kept in pairs in glass beakers $(600 \mathrm{~mL})$. Pollen $(3.0 \mathrm{~g})$ and water $(5.0 \mathrm{~mL}$ on filter paper) were provided, along with oviposition sites. Eight replicate beakers were estab- lished per treatment and for their respective controls. After $48 \mathrm{~h}$, the oviposition rate was evaluated by counting eggs.

The live larvae were transferred into $200-\mathrm{mL}$ plastic cups with autoclaved moist soil and kept for pupation in an environmental chamber at $30 \pm 1{ }^{\circ} \mathrm{C}$. To avoid desiccation and growth of fungi (Lundie 1940; Mürrle and Neumann 2004), the cups were covered with perforated plastic foil. As a result of the formic and oxalic acid treatments, the numbers of live larvae varied between 13 and 25 . Therefore, only five replicates could be tested for larvae treated with formic acid, but all eight replicates were tested for those treated with oxalic acid or controls. After 16 days, the numbers of emerged beetles were recorded, since this has been shown previously to be a suitable time to complete development under the given environmental conditions (Buchholz et al. 2006).

\subsection{Field experiments}

\subsubsection{Treatments of adult small hive beetles}

The field experiments with adult SHB were performed in an apiary in Umatilla, Florida (USA) during June-September 2004. Two weeks before the experiment, 20 queen-right colonies (predominantly A. mellifera ligustica) of similar size (approximately six frames of bees) were set up for each of the three treatments described below. The adult SHBs in the naturally infested colonies were carefully removed from each frame and all other hive parts with an aspirator (Spiewok et al. 2007). They were kept on a honey and water diet at room temperature until they were used for the artificial re-infestation of the bee colonies.

Formic acid (60\%) treatment with Nassenheider ${ }^{\circledR}$ evaporator for 13 days Following established European protocols for $V$. destructor treatments (Rademacher et al. 1999), Nassenheider ${ }^{\circledR}$ evaporators (Weiland, Dahlwitz Hoppegarten, Germany) were filled with $180 \mathrm{~mL}$ of either $60 \%$ formic acid or water (controls). They were affixed to frames and placed in the hive at position 2, next to a honey frame. The liquids were evaporated via a wick $(50 \times$ $60 \mathrm{~mm}$ ). Tin plates (oven liner, $463 \times 400 \mathrm{~mm}$, Pactif 
Co., Illinois, USA), which could be easily removed to assess adult SHB mortality, were placed on the bottom boards. Then, 100 adult SHBs were placed on the frame tops and the hive was quickly closed. The mortality was assessed on a daily basis by counting and removing dead adult SHBs from the tin plates on the bottom board. The reservoirs of the evaporators were refilled as required to ensure continuous evaporation. After 13 days, all remaining adult SHBs were collected from each frame and hive part and then counted.

\section{Formic acid (85\%) treatment with sponge} tissues for $13 h$ To obtain a rapid distribution of the volatile agent, the formic acid $(85 \%)$ was evaporated on a diagnostic tray covered with a grill (white plastic; $250 \times 300 \times 7 \mathrm{~mm}$; Günther Spritzgußtechnik GmbH, Kaufbeuren-Neugablonz, Germany). Sponge tissues $(175 \times 195 \mathrm{~mm}$, Wettpex $)$ were placed on the plastic tray and saturated with either $20 \mathrm{~mL}$ formic acid or water (control). When each tray was covered with its grill to prevent bee access, it was placed onto the centre of the bottom board. Then, 100 adult beetles were introduced into each colony. As daily temperatures were above $25^{\circ} \mathrm{C}$, the experiment was conducted overnight to avoid the rapid evaporation of the acid. All live and dead adult beetles were recaptured and counted after $13 \mathrm{~h}$.

Oxalic acid heat application Directly before treatment, 100 adult SHBs were placed on the frame tops of the colonies (ten replicates per treatment and control) and the hives were quickly closed. To evaporate the oxalic acid, a Varrox ${ }^{\circledR}$ evaporator (Andermatt BioVet AG, Switzerland) was filled with 2 g oxalic acid (dihydrate crystals, 99\%) and placed on the bottom board of each hive. The device was powered with a $12-\mathrm{V}$ battery. To provide a continuous distribution of the oxalic acid fumes, the hive entrances were blocked with newspaper during the $2.5 \mathrm{~min}$ of heat treatment and for another $15 \mathrm{~min}$ after the device was removed. For the controls, the Varrox $^{\circledR}$ evaporator was heated without any substance. After $24 \mathrm{~h}$, all adult SHBs were collected from five treated and five untreated hives. The same procedure was repeated after another $24 \mathrm{~h}$ with the remaining ten colonies.

\subsubsection{Treatments of SHB eggs and larvae}

The field experiments with SHB eggs and larvae were performed in an apiary at Beltsville, Maryland, USA during June-August 2005. The treatments for SHB eggs and larvae, using formic and oxalic acid, were performed in the way as for adult beetles, but with two modifications. Instead of 13 days for the long-term treatment with Nassenheider ${ }^{\circledR}$ evaporators, the SHB life stages were exposed for only 4 days of $60 \%$ formic acid fumigation. In addition, to limit non-target effects on bees, we used $60 \%$ instead of $85 \%$ formic acid for the treatment with sponge tissues on diagnostic trays.

To introduce SHB eggs and larvae into the beehive and expose them to the agents, the following method was developed (Figure 2): Comb frames were each equipped with two sections of plastic cells $\left(\right.$ Permacomb ${ }^{\circledR} 12.5 \times 17 \mathrm{~cm}$ and $8.5 \times 6 \mathrm{~cm}$ ) mounted on a non-drawn plastic middle wall. A circular section $(8.5 \mathrm{~cm}$ in diameter) of the larger Perma$\mathrm{comb}^{\circledR}$ piece was filled with $40 \mathrm{~g}$ pollen-honey paste (2:1) to provide nutrition. Young SHB larvae $(n=25$; aged $<48 \mathrm{~h}$ after hatching) were transferred into the centre of this food section. The combs were sprayed with $\sim 5 \mathrm{~mL}$ water to limit larval dehydration. Eggs (aged $<20 \mathrm{~h} ; n=152 \pm 72$ ) laid on oviposition sites were affixed to the smaller pieces of Permacomb ${ }^{\circledR}$. Pollen-honey paste $(2.5 \mathrm{~g})$ and water $(5.0 \mathrm{~mL})$ were each placed into two rows of Permacomb ${ }^{\circledR}$ cells, adjoining the oviposition aid to avoid cannibalism and to enable hatching larvae to reach food and moisture easily. This "observation frame" was covered with metal gauze (mesh width, $<2 \mathrm{~mm}$ ) to avoid removal of SHB eggs and larvae (Neumann and Härtel 2004) and food consumption by the bees. The frame was set on position 5 in the middle of the colony for all experiments. After 4 days, each treatment was terminated and the number of hatched larvae was estimated in the laboratory by evaluating the egg shells. Those appearing clear under microscopic magnification $(400 \times$, phase contrast) were classified as "hatched" and those containing white structures (SHB embryos) as "non-hatched". The larvae from the larger Permacomb ${ }^{\circledR}$ were kept in separate containers in an incubator at $30^{\circ} \mathrm{C}$ with pollen-honey paste and water ad libitum until they had reached the wandering stage, after which they 


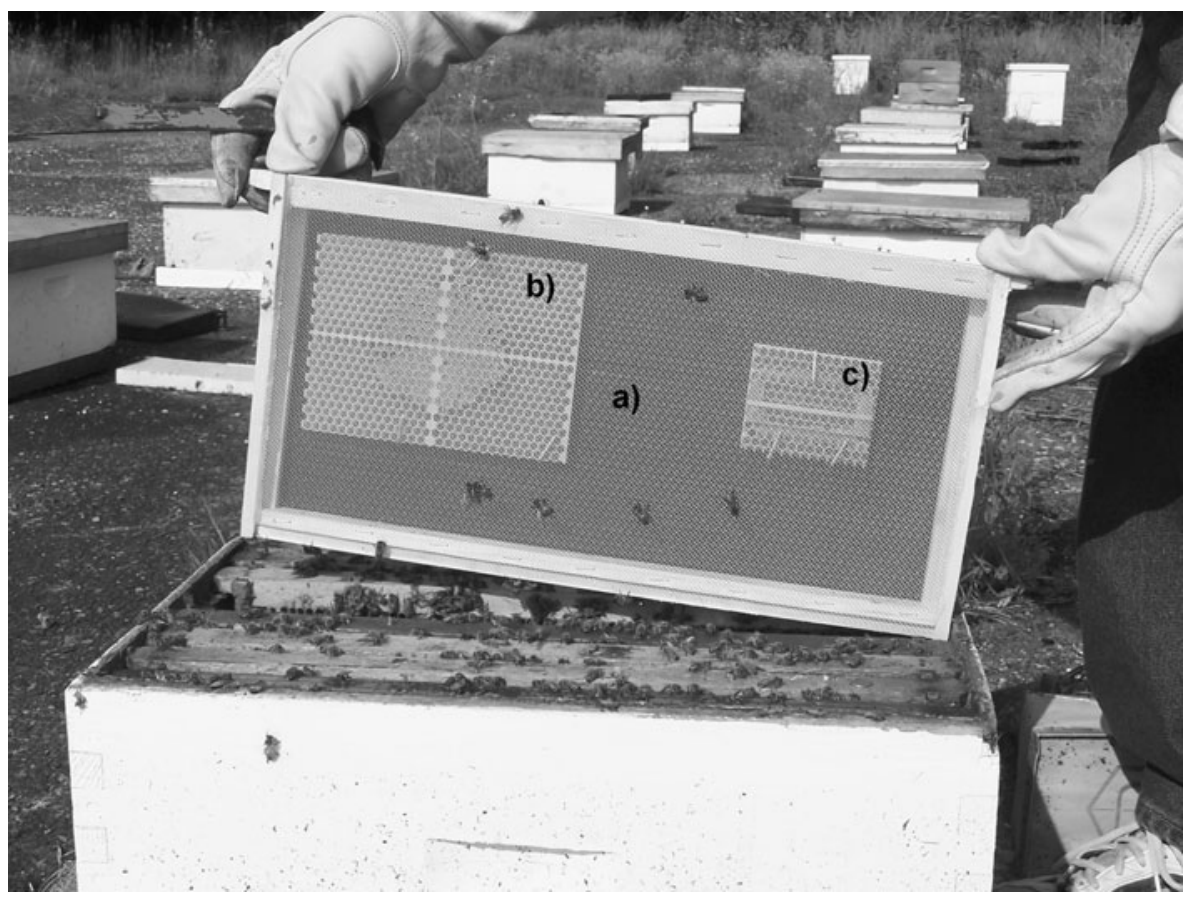

Figure 2. Design of an observation frame used for treating SHBs with organic acids in active beehives. The frame is covered with bee-proof wire mesh and placed in the centre of the beehive. $a$, non-drawn plastic middle wall carrying artificial comb pieces; $b$, Permacomb ${ }^{\circledR}$ section for larvae with circular section $(8.5 \mathrm{~cm}$ in diameter) of $40 \mathrm{~g}$ pollen-honey paste $(2: 1)$; $c$, Permacomb ${ }^{\circledR}$ section for eggs on oviposition slides, with $2.5 \mathrm{~g}$ pollen-honey paste and $5.0 \mathrm{~mL}$ water.

were counted. Ten replicates were performed for both the treatment and the control.

\subsubsection{Treatment of SHB on stored combs with acetic acid for 7 days}

In Richmond, Australia, an experiment was performed in 2006 to investigate the effects of acetic acid on SHB reproduction in honey houses. After their manual extraction, honey frames were transferred into colonies for $24 \mathrm{~h}$ to be cleaned by the bees, which thereby also removed possible SHB eggs or larvae (Neumann and Härtel 2004; Spiewok and Neumann 2006). The cleaned combs were then stored in plastic bags for two days at $4^{\circ} \mathrm{C}$ to kill any possibly remaining beetles and to avoid re-infection by adult SHBs. The frames were then placed in single Langstroth hive boxes (seven replicates per treatment and control), with upside-down plastic lids in place of bottom boards. The boxes were set up in an extracting room at room temperature $\left(23 \pm 3^{\circ} \mathrm{C}\right)$. Sponge tissues were also set on the frame tops and saturated with either $20 \mathrm{~mL}$ acetic acid $(65 \%)$ or water as control. Per replicate, 20 unsexed adult beetles (aged approximately 4 weeks) were obtained from rearing containers where they had already laid eggs, and they were transferred into a box that was quickly closed with a lid. The gaps between the lids and boxes were sealed with masking tape to prevent any SHB escape and to maintain a high acid concentration. After 7 days, the boxes were opened to assess mortality of adult SHBs and the presence of SHB eggs and young larvae.

\subsection{Data analysis}

Data from laboratory short-term treatments were analysed using Spearman rank correlations to detect 
dose-dependent mortality within treatment substances and SHB life stages (adults, larvae, and eggs). Kruskal-Wallis tests with multiple comparisons as post-hoc tests were conducted to compare treatments with respective controls $(\alpha=0.05)$. Treatments in laboratory long-term and all field experiments were compared with their respective controls using MannWhitney $U$ tests $(\alpha=0.05)$. Whenever required, mortalities in the treatments were Abbott-adjusted (Abbott 1925). All analyses were performed using the programme Statistica ${ }^{(}$.

\section{RESULTS}

All values are given as means \pm SD. If not mentioned in the text, statistical details are shown in the corresponding tables.

\subsection{Laboratory experiments}

\subsubsection{Treatments of SHBs with organic acids and thymol for $72 \mathrm{~h}$}

The results from treatments with evaporating substances (formic acid, acetic acid, and thymol) are shown in Table I. All tested life stages showed a strong, positive correlation between the dose of formic acid and the induced mortality. After $72 \mathrm{~h}$, formic acid treatments with concentrations of $2.0 \mathrm{~mL}$ for adults, $\geq 0.75 \mathrm{~mL}$ for larvae, and $\geq 0.5 \mathrm{~mL}$ for eggs resulted in significantly higher mortalities in comparison to their respective controls. Compared to their controls, none of the acetic acid dosages resulted in significantly higher numbers of dead adults or eggs. In contrast, all larvae were killed with doses $\geq 1.5 \mathrm{~mL}$ of acetic acid. The mortality of larvae treated with acetic acid indicated a positive dose-mortality relationship. None of the evaluated amounts of thymol increased SHB mortality significantly, regardless of the tested life stages.

The results of the experiments where SHBs had been treated with lactic or oxalic acid are shown in Table II. None of the tested dosages of lactic acid resulted in significantly increased mortality of adults and eggs. However, larvae showed a positive dose-mortality correlation, and dosages of $\geq 1.0 \mathrm{~mL}$ lactic acid resulted in significantly higher mortality than controls. Oxalic acid indicated a positive dose-mortality association for adults and larvae. Compared to the control, significantly more adults died in the highest concentration $(2.0 \mathrm{~mL})$ of oxalic acid. All larvae were killed with treatments of $\geq 0.75 \mathrm{~mL}$ oxalic acid. Trials with eggs treated with $\leq 1.0 \mathrm{~mL}$ oxalic acid showed fungal infestation, probably caused by spores on the fruit. In trials with $1.0 \mathrm{~mL}$ and $2.0 \mathrm{~mL}$ oxalic acid, more than half of the eggs were dead after $72 \mathrm{~h}$.

Reference measurements All concentrations (parts per million) of formic or acetic acid measured from air samples declined after $24 \mathrm{~h}$ (Table III). Formic acid concentrations of $\geq 160 \mathrm{ppm}$ were obtained from dosages of $\geq 0.5 \mathrm{~mL}$ after 6 and $24 \mathrm{~h}$ while the highest dosage of $2.0 \mathrm{~mL}$ formic acid, resulted in values of $\geq 680 \mathrm{ppm}(6 \mathrm{~h})$ and $960 \mathrm{ppm}$ (24 h). The maximum concentration of acetic acid decreased from $880 \mathrm{ppm}$ after $6 \mathrm{~h}$ to $60 \mathrm{ppm}$ after $72 \mathrm{~h}$. In contrast, levels of thymol compounds in the air samples increased with time, resulting in the highest values after $72 \mathrm{~h}$ (Table III).

\subsubsection{Long-term effects of formic and oxalic acid on larval and adult SHBs}

After treatment with $2.0 \mathrm{~mL} 85 \%$ formic acid, adult SHBs laid significantly fewer eggs (8.5 \pm 10.3) within $48 \mathrm{~h}$ in comparison to untreated adults $(59.2 \pm 34.2 ; U=6 ; P<0.01)$. In contrast, the numbers of eggs $(33.5 \pm 22.9)$ laid by adults treated with $0.5 \mathrm{~mL}$ oxalic acid [35 g/L] did not differ significantly from the controls $(46.0 \pm 55.6$; $U=32 ; P>0.95)$.

The numbers of emerged adults $(89.3 \pm 10.7)$ that developed from larvae previously treated with formic acid were not significantly different from those that emerged from the control (78.1 $\pm 26.4 ; U=23 ; P>0.31)$. The same was true for adults that emerged from larvae previously 
Table I. Abbott-adjusted mortalities [percent] of adult SHBs, wandering larvae, and eggs $72 \mathrm{~h}$ after application of organic acids and thymol by evaporation in the laboratory (adults and larvae: six replicates each; eggs: eight replicates, with 25 individuals per replicate).

\begin{tabular}{|c|c|c|c|c|}
\hline \multicolumn{2}{|c|}{ Substance } & \multicolumn{3}{|c|}{ Mortality } \\
\hline & & Adults & Larvae & Eggs \\
\hline \multirow[t]{6}{*}{ Formic acid } & $0.125 \mathrm{~mL}$ & $0.7 \pm 1.6 \mathrm{c}$ & $1.0 \pm 2.6 \mathrm{~b}$ & $4.9 \pm 8.3 \mathrm{bc}$ \\
\hline & $0.25 \mathrm{~mL}$ & $1.9 \pm 2.1 b c$ & $18.0 \pm 10.9 \mathrm{ab}$ & $18.4 \pm 13.5 \mathrm{abc}$ \\
\hline & $0.5 \mathrm{~mL}$ & $3.3 \pm 6.2 \mathrm{bc}$ & $69.5 \pm 16.8 \mathrm{ab}$ & $75.0 \pm 22.3 \mathrm{ab}$ \\
\hline & $0.75 \mathrm{~mL}$ & $49.4 \pm 20.4^{\mathrm{a} a c}$ & $97 \pm 0^{\mathrm{a}} \mathrm{a}$ & $86.5 \pm 10.5 \mathrm{a}$ \\
\hline & $1 \mathrm{~mL}$ & $91.3 \pm 5.9 \mathrm{ab}$ & $97 \pm 0 \mathrm{a}$ & $86.5 \pm 10.5 \mathrm{a}$ \\
\hline & $2 \mathrm{~mL}$ & $100.0 \pm 0.0 \mathrm{a}$ & $97 \pm 0 \mathrm{a}$ & $86.5 \pm 10.5 \mathrm{a}$ \\
\hline $\mathrm{H}_{2} \mathrm{O}$ (control) & $1 \mathrm{~mL}$ & $0 \pm 0^{\mathrm{a}} \mathrm{bc}$ & $3.1 \pm 4.0^{\mathrm{a}} \mathrm{b}$ & $13.5 \pm 10.5 \mathrm{c}$ \\
\hline $\begin{array}{l}\text { Kruskal-Wallis } \\
\text { test }\end{array}$ & & $H_{6,38}=32.5 ; P<0.001$ & $H_{6,36}=36.4 ; P<0.001$ & $H_{6,56}=43.2 ; P<0.001$ \\
\hline Spearman rank & & $R=0.89 ; P<0.001$ & $R=0.94 ; P<0.001$ & $R=0.74 ; P<0.001$ \\
\hline \multirow[t]{4}{*}{ Acetic acid } & $0.5 \mathrm{~mL}$ & $0.7 \pm 1.6 \mathrm{a}$ & $0 \pm 0 \mathrm{~b}$ & $3.3 \pm 5.2 \mathrm{a}$ \\
\hline & $1 \mathrm{~mL}$ & $0.7 \pm 1.6 \mathrm{a}$ & $17.6 \pm 10.7 \mathrm{ab}$ & $1.8 \pm 4.4 \mathrm{a}$ \\
\hline & $1.5 \mathrm{~mL}$ & $0.7 \pm 1.6 \mathrm{a}$ & $97 \pm 0 \mathrm{a}$ & $3.9 \pm 5.4 \mathrm{a}$ \\
\hline & $2 \mathrm{~mL}$ & $0.7 \pm 1.6 \mathrm{a}$ & $97 \pm 0 \mathrm{a}$ & $10.6 \pm 11.7 \mathrm{a}$ \\
\hline $\mathrm{H}_{2} \mathrm{O}$ (control) & $1 \mathrm{~mL}$ & $0 \pm 0^{\mathrm{a}} \mathrm{a}$ & $3.1 \pm 4.0^{\mathrm{a}} \mathrm{b}$ & $13.5 \pm 10.5 \mathrm{a}$ \\
\hline $\begin{array}{l}\text { Kruskal-Wallis } \\
\text { test }\end{array}$ & & $H_{4,28}=0.8 ; P>0.94$ & $H_{4,28}=26.7 ; P<0.001$ & $H_{4,40}=8.6 ; P>0.07$ \\
\hline Spearman rank & & $R=0 ; P>0.99$ & $R=0.94 ; P<0.001$ & $R=0.28 ; P>0.12$ \\
\hline \multirow[t]{3}{*}{ Thymol } & $10 \mathrm{mg}$ & $2.7 \pm 3.3 \mathrm{a}$ & $1.0 \pm 2.6 \mathrm{a}$ & $8.6 \pm 10.6 \mathrm{a}$ \\
\hline & $20 \mathrm{mg}$ & $8.6 \pm 11.1 \mathrm{a}$ & $2.1 \pm 4.2 \mathrm{a}$ & $2.6 \pm 5.9 \mathrm{a}$ \\
\hline & $50 \mathrm{mg}$ & $0 \pm 0 \mathrm{a}$ & $0 \pm 0 \mathrm{a}$ & $4.2 \pm 8.9 \mathrm{a}$ \\
\hline $\mathrm{H}_{2} \mathrm{O}$ (control) & $1 \mathrm{~mL}$ & $0 \pm 0^{\mathrm{a}} \mathrm{a}$ & $3.1 \pm 4.0^{\mathrm{a}} \mathrm{a}$ & $13.5 \pm 10.5 \mathrm{a}$ \\
\hline $\begin{array}{l}\text { Kruskal-Wallis } \\
\text { test }\end{array}$ & & $H_{3,22}=8.5 ; P<0.04$ & $H_{3,22}=3.4 ; P>0.33$ & $H_{3,32}=5.6 ; P>0.13$ \\
\hline Spearman rank & & $R=-0.38 ; P>0.12$ & $R=-0.18 ; P>0.47$ & $R=-0.14 ; P>0.50$ \\
\hline
\end{tabular}

Results are shown as means \pm SD with results of Kruskal-Wallis tests and multiple comparisons as post-hoc tests, Spearman's rank correlations with $\alpha=0.05$. Values followed by different letters indicate significant differences within treatments and life stages

${ }^{\mathrm{a}}$ Four replicates

treated with oxalic acid $(91.2 \pm 6.0)$ and the respective control $(93.3 \pm 9.4 ; U=17 ; P>0.10)$.

\subsection{Field experiments}

\subsubsection{Treatments of adult SHBs}

The results of field experiments with infested beehives treated with formic and oxalic acid are shown in Table IV. The application of $60 \%$ formic acid with Nassenheider ${ }^{\circledR}$ evapo- rators did not result in significant differences compared to the control after 13 days of treatment, neither in numbers of recaptured adults nor in missing adults or adult mortality. The same was true for the application of $85 \%$ formic acid on sponge tissues in diagnostic trays from which the acid evaporated for an overnight period of $13 \mathrm{~h}$. The heat application $\left(\right.$ Varrox ${ }^{\circledR}$ ) of oxalic acid on SHB infested bee colonies showed no significant differences in adult mortality or in numbers of living 
Table II. Abbott-adjusted mortalities [percent] of adult SHBs, wandering larvae, and eggs $72 \mathrm{~h}$ after contact application of organic acids in the laboratory (adults and larvae: six replicates each; eggs: eight replicates; with 25 individuals per replicate).

\begin{tabular}{lllll}
\hline Substance & {$[\mathrm{mL}]$} & \multicolumn{3}{c}{ Mortality } \\
\cline { 3 - 5 } & & \multicolumn{1}{c}{ Adults } & \multicolumn{1}{c}{ Larvae } & \multicolumn{1}{c}{ Eggs } \\
\hline Lactic acid & 0.5 & $0 \pm 0 \mathrm{a}$ & $13.8 \pm 24.3 \mathrm{bc}$ & $19.9 \pm 32.5 \mathrm{ab}$ \\
& 0.75 & $0 \pm 0 \mathrm{a}$ & $81.3 \pm 8.2 \mathrm{ab}$ & $12.4 \pm 12.7 \mathrm{a}$ \\
& 1 & $0 \pm 0 \mathrm{a}$ & $77.8 \pm 22.4 \mathrm{ac}$ & $9.2 \pm 12.4 \mathrm{ab}$ \\
& 2 & $0.1 \pm 0.2 \mathrm{a}$ & $97.3 \pm 2.1 \mathrm{a}$ & $11.8 \pm 16.3 \mathrm{ab}$ \\
$\mathrm{H}_{2} \mathrm{O}$ (control) & 1 & $1.3 \pm 2.0 \mathrm{a}$ & $0.7 \pm 1.6 \mathrm{~b}$ & $11.5 \pm 6.6 \mathrm{~b}$ \\
Kruskal-Wallis test & $H_{4,30}=4.0 ; P>0.40$ & $H_{4,30}=24.7 ; P<0.001$ & $H_{4 ; 40}=11.03 ; P>0.03$ \\
Spearman rank & & $R=0.28 ; P>0.18$ & $R=0.84 ; P<0.001$ & $R=-0.07 ; P>0.69$ \\
Oxalic acid & 0.25 & $0 \pm 0 \mathrm{~b}$ & $83.3 \pm 23.1 \mathrm{ab}$ & - \\
& 0.5 & $1.4 \pm 2.0 \mathrm{ab}$ & $88.7 \pm 16.9 \mathrm{ab}$ & - \\
& 0.75 & $0 \pm 0 \mathrm{~b}$ & $99.3 \pm 1.6 \mathrm{a}$ & - \\
& 1 & $1.4 \pm 2.0 \mathrm{ab}$ & $99.3 \pm 1.6 \mathrm{a}$ & $53.5 \pm 11.9 \mathrm{a} \mathrm{a}$ \\
& 2 & $28.4 \pm 17.6 \mathrm{a}$ & $99.3 \pm 1.6 \mathrm{a}$ & $58.0 \pm 15.2 \mathrm{a}$ \\
$\mathrm{H}_{2} \mathrm{O}$ (control) & 1 & $1.3 \pm 2.0 \mathrm{~b}$ & $0.7 \pm 1.6 \mathrm{~b}$ & $11.5 \pm 6.6 \mathrm{~b}$ \\
Kruskal-Wallis test & & $H_{5,36}=24.6 ; P<0.001$ & $H_{5,36}=22.0 ; P<0.001$ & $H_{2,20}=14.9 ; P<0.001$ \\
Spearman rank & & $R=0.64 ; P<0.001$ & $R=0.44 ; P<0.015$ & - \\
& & &
\end{tabular}

Values are shown as means $\pm \mathrm{SD}$ and the results of Kruskal-Wallis tests and Spearman rank correlations $(\alpha=0.05)$. Different letters indicate significant differences within treatments and life stages (multiple comparisons as post-hoc tests)

${ }^{\text {a }}$ Four replicates

Table III. Concentrations of formic and acetic acid [parts per million] and thymol [microgrammes per litre] after time [hours] in air samples of experimental design for laboratory SHB treatment.

\begin{tabular}{clrrrr}
\hline Substance & Dosage & $6 \mathrm{~h}$ & $24 \mathrm{~h}$ & $48 \mathrm{~h}$ & $72 \mathrm{~h}$ \\
\hline Formic acid $[\mathrm{ppm}]$ & $0.125 \mathrm{~mL}$ & 28 & 22 & 12 & 8 \\
& $0.25 \mathrm{~mL}$ & 80 & 24 & 12 & 10 \\
& $0.5 \mathrm{~mL}$ & $\mathbf{1 6 0}$ & $\mathbf{1 6 0}$ & 50 & 20 \\
& $0.75 \mathrm{~mL}$ & $\mathbf{2 4 0}$ & $\mathbf{2 4 0}$ & 70 & 24 \\
& $1.0 \mathrm{~mL}$ & $\mathbf{3 2 0}$ & $\mathbf{4 0 0}$ & 140 & 80 \\
& $2.0 \mathrm{~mL}$ & $\mathbf{( 6 8 0 )}$ & $\mathbf{9 6 0 )}$ & 200 & 100 \\
Acetic acid $[\mathrm{ppm}]$ & $0.5 \mathrm{~mL}$ & 130 & 36 & 12 & 6 \\
& $1.0 \mathrm{~mL}$ & 320 & 220 & 80 & 36 \\
& $1.5 \mathrm{~mL}$ & 560 & 560 & 120 & 100 \\
Thymol $[\mu \mathrm{g} / \mathrm{L}]$ & $2.0 \mathrm{~mL}$ & 880 & 480 & 100 & 60 \\
& $10 \mathrm{mg}$ & 0.6 & 1.8 & 1.4 & 1.9 \\
& $20 \mathrm{mg}$ & 1.1 & 2.7 & 3.0 & 2.9 \\
& $50 \mathrm{mg}$ & 3.3 & 3.5 & 4.7 & $\mathbf{6 . 4}$
\end{tabular}

Values effective against Varroa destructor mites (Charrière et al. 1992; Bolli et al. 1993) are in bold. Values in parentheses are toxic to bees (Charrière et al. 1992; Bolli et al. 1993) and therefore cannot be recommended for application in hives 
Table IV. All recaptured, dead recaptured, and missing adult A. tumida (Abbott-adjusted mortality) after treatments with organic acids (controls for formic acid: water; for oxalic acid: heat without substance) in bee colonies (ten replicate hives per trial with 100 introduced adults per hive).

\begin{tabular}{|c|c|c|c|c|c|c|c|c|}
\hline \multirow{3}{*}{$\begin{array}{l}\text { Agent } \\
\text { Application }\end{array}$} & \multicolumn{4}{|c|}{ Formic acid (FA) } & \multicolumn{4}{|c|}{ Oxalic acid dihydrate (OAD) } \\
\hline & \multicolumn{2}{|c|}{$\begin{array}{l}\text { Nassenheider }{ }^{\mathbb{R}} \text {, } \\
13 \text { days }\end{array}$} & \multicolumn{2}{|c|}{$\begin{array}{l}\text { Diagnostic } \\
\text { trays, } 13 \mathrm{~h}\end{array}$} & \multicolumn{2}{|c|}{$\begin{array}{l}\text { Heat evaporation, } \\
24 \mathrm{~h}^{\mathrm{a}}\end{array}$} & \multicolumn{2}{|c|}{$\begin{array}{l}\text { Heat evaporation, } \\
48 \mathrm{~h}^{\mathrm{a}}\end{array}$} \\
\hline & $\begin{array}{l}\text { Treatment } \\
\text { (FA 60\%) }\end{array}$ & $\begin{array}{l}\text { Control } \\
\text { (water) }\end{array}$ & $\begin{array}{l}\text { Treatment } \\
\text { (FA 85\%) }\end{array}$ & $\begin{array}{l}\text { Control } \\
\text { (water) }\end{array}$ & $\begin{array}{l}\text { Treatment } \\
(2 \mathrm{~g} \\
\text { OAD) }\end{array}$ & $\begin{array}{l}\text { Control } \\
\text { (heat } \\
\text { only) }\end{array}$ & $\begin{array}{l}\text { Treatment } \\
(2 \mathrm{~g} \\
\text { OAD })\end{array}$ & $\begin{array}{l}\text { Control } \\
\text { (heat } \\
\text { only) }\end{array}$ \\
\hline $\begin{array}{l}\text { All recaptured } \\
\text { adults [\%] }\end{array}$ & $\begin{array}{r}27.3 \pm \\
12.4\end{array}$ & $\begin{array}{r}28.6 \pm \\
15.4\end{array}$ & $\begin{array}{r}87.2 \pm \\
31.2\end{array}$ & $\begin{array}{r}92.7 \pm \\
17.8\end{array}$ & $\begin{array}{r}42.4 \pm \\
15.2\end{array}$ & $\begin{array}{r}45.0 \pm \\
10.8\end{array}$ & $38.4 \pm 4.0$ & $\begin{array}{r}33.8 \pm \\
10.1\end{array}$ \\
\hline MWU & $\begin{array}{l}U=50 \\
P>0.96\end{array}$ & & $\begin{array}{l}U=46 \\
P>0.73\end{array}$ & & $\begin{array}{l}U=11 \\
P>0.75\end{array}$ & & $\begin{array}{l}U=8 \\
P>0.29\end{array}$ & \\
\hline $\begin{array}{l}\text { Dead } \\
\text { recaptured } \\
\text { adults [\%] }\end{array}$ & $0 \pm 0$ & $\begin{array}{r}37.8 \pm \\
21.3\end{array}$ & $0 \pm 0$ & $0.4 \pm 1.1$ & $\begin{array}{r}10.1 \pm \\
21.2\end{array}$ & $0 \pm 0$ & $0 \pm 0$ & $1.5 \pm 3.4$ \\
\hline MWU & $\begin{array}{l}U=50 \\
P>0.99\end{array}$ & & $\begin{array}{l}U=40 \\
\quad P>0.45\end{array}$ & & $\begin{array}{l}U=8 ; \\
P>0.29\end{array}$ & & $\begin{array}{l}U=10 \\
P>0.60\end{array}$ & \\
\hline $\begin{array}{l}\text { Missing } \\
\text { adults [\%] }\end{array}$ & $\begin{array}{r}72.7 \pm \\
12.4\end{array}$ & $\begin{array}{r}71.4 \pm \\
15.4\end{array}$ & $\begin{array}{r}12.8 \pm \\
31.2\end{array}$ & $7.3 \pm 17.8$ & $\begin{array}{r}57.6 \pm \\
15.2\end{array}$ & $\begin{array}{r}55.0 \pm \\
10.8\end{array}$ & $\begin{array}{r}61.6 \pm \\
4.00\end{array}$ & $\begin{array}{r}66.2 \pm \\
10.1\end{array}$ \\
\hline MWU & $\begin{array}{l}U=50 \\
\quad P>0.96\end{array}$ & & $\begin{array}{l}U=46 \\
P>0.73\end{array}$ & & $\begin{array}{l}U=11 \\
\quad P>0.75\end{array}$ & & $\begin{array}{l}U=8 \\
P>0.29\end{array}$ & \\
\hline
\end{tabular}

Means \pm SD and comparisons between treatments and respective controls are shown

$M W U$ Mann-Whitney $U$ tests, $\alpha=0.05$

${ }^{\mathrm{a}}$ Five replications

recaptured beetles compared to the control, regardless of whether adults were sampled after 24 or $48 \mathrm{~h}$.

For both formic acid and oxalic acid treatments, we observed that with increasing duration of the experiments, the numbers of missing adult SHBs increased. This was true for both the treatments and the controls.

\subsubsection{Treatments of SHB eggs and larvae}

In comparison to the controls, the application of $60 \%$ formic acid for 4 days with Nassenheider ${ }^{\circledR}$ evaporators or diagnostic trays did not result in significant differences, either in numbers of larvae that hatched from introduced eggs or in the development of young to wandering larvae (Table V). The same was true for the treatments with oxalic acid (Varrox $\left.{ }^{\circledR}\right)$.

\subsubsection{Treatment of SHB on stored combs with acetic acid for 7 days}

There was no significant difference in mortality of adult SHBs between treatment (23.2 \pm $18.9 \%)$ and control (14.4 $\pm 13.4 \% ; U=17 ; P>$ 0.30 ) after 7 days of use of acetic acid. In six out of seven treated hive bodies, young larvae were found on extracted honey frames, which did not differ significantly from control trials, where all hive bodies were infested with young larvae $(U=21 ; P>0.65)$.

\section{DISCUSSION}

\subsection{Laboratory experiments}

The main aim of our study was to kill the adult beetles with the alternative agents before 
Table V. Hatched SHB larvae [percent] from introduced eggs and numbers of wandering larvae developing from young ones during treatments with organic acids in bee colonies.

\begin{tabular}{|c|c|c|c|c|c|c|}
\hline \multirow{3}{*}{$\begin{array}{l}\text { Agent } \\
\text { Application }\end{array}$} & \multicolumn{4}{|c|}{ Formic acid $(60 \%)$} & \multicolumn{2}{|c|}{ Oxalic acid dihydrate } \\
\hline & \multicolumn{2}{|c|}{ Nassenheider ${ }^{\circledR}$ evaporator } & \multicolumn{2}{|c|}{ Diagnostic trays } & \multicolumn{2}{|c|}{ Heat evaporation ( 2 g crystals $99 \%$ ) } \\
\hline & Treatment & Control & Treatment & Control & Treatment & Control \\
\hline Hatched larvae & $65.5 \pm 14.7$ & $63.4 \pm 17.7$ & $54.3 \pm 13.4$ & $56.10 \pm 8.0$ & $67.4 \pm 14.1$ & $73.2 \pm 15.2^{\mathrm{a}}$ \\
\hline MWU & \multicolumn{2}{|c|}{$U=49 ; P>0.93$} & \multicolumn{2}{|c|}{$U=46 ; P>0.76$} & \multicolumn{2}{|l|}{$U=29 ; P>0.11$} \\
\hline Wandering larvae & $34.8 \pm 26.1$ & $29.2 \pm 27.5$ & $80.4 \pm 13.8$ & $81.2 \pm 11.0$ & $78.7 \pm 14.7^{\mathrm{a}}$ & $82.7 \pm 11.7^{\mathrm{a}}$ \\
\hline MWU & \multicolumn{2}{|c|}{$U=40 ; P>0.44$} & \multicolumn{2}{|c|}{$U=48 ; P>0.87$} & $U=46 ; P>0.76$ & \\
\hline
\end{tabular}

Per treatment and control: ten replicate hives each with $152 \pm 72$ eggs (defined as $n=100 \%$ ) and 25 wandering larvae. Means \pm $\mathrm{SD}$ and comparisons between treatments and respective controls are shown

$M W U$, Mann-Whitney $U$ test, $\alpha=0.05$

${ }^{\text {a }}$ Nine replicates

they were able to reproduce. However, the wandering larvae turned out to be the most susceptible stage to the tested organic acids. At the commencement of our studies, we expected that eggs would be most susceptible, as they are more exposed to the substances due to their small size and disadvantageous volume/surface area ratio compared to the much larger wandering larvae and adults. Although the transfer of the eggs might have had a negative effect on their survival, the hatching rate in the controls was $>85 \%$. For future laboratory experiments, it may be better to leave the fragile eggs in their oviposition sites so they can be easily counted and possible injuries to the eggs during transfer would be avoided. In addition, eggs in between two slides simulate their natural situation inside the capped brood cells or in tight crevices. Therefore, in our field experiment, we left the eggs on the slides.

None of the concentrations of thymol showed any effect on SHB mortality of the tested life stages. According to previous laboratory experiments (Imdorf et al. 1995), the thymol concentration for an effective control of $V$. destructor should be between 5 and $15 \mu \mathrm{g}$ per litre of air. In our laboratory experiments, this amount was achieved with the highest dosage of $50 \mathrm{mg}$ after $72 \mathrm{~h}$. In $V$. destructor treatments, the essential oil is usually applied in long-term treatments of 2 to 4 weeks (Imdorf et al. 1999; Floris et al. 2004). However, a bee colony can either be heavily infested with or even be killed by SHBs within 4 weeks (Elzen et al. 1999; Neumann and Elzen 2004). Furthermore, Ellis and Delaplane (2006) showed that the thymolbased product Apilife $\operatorname{Var}^{\mathrm{TM}}$ had no effect on the host-finding ability of adult SHBs. Therefore, thymol was ruled out as an agent worthy of being further tested in the field.

For lactic and acetic acid, positive dosagemortality correlations were recorded for the larval stage only. All the air concentrations of acetic acid that were measured in the glass boxes were lower than those that would be reached in a regular treatment against wax moths (Imdorf 2005).

The mortalities of adults, wandering larvae, and eggs of SHB were correlated with increasing concentrations of formic acid and oxalic acid. The measured formic acid concentrations in the atmospheres of the laboratory trials of $\geq 160$ ppm would have been effective against varroa mites within beehives (Imdorf 2005). Values of $\geq 680 \mathrm{ppm}$ would cause severe impacts on honeybee colonies, such as disorientation of bees (Przewozny et al. 2003), queen loss, and/or dead brood (Gregorc et al. 2004). 
Such concentrations should therefore not be applied in a colony. Levels of 320-400 ppm were measured after 6 and $24 \mathrm{~h}$ when $1.0 \mathrm{~mL}$ formic acid evaporated. These data would be comparable to $24-\mathrm{h}$ values of a short-term treatment with $60 \%$ formic acid (Charrière et al. 1992).

We were surprised that fungal presence occurred only in the egg trial with oxalic acid. We therefore assume that the growth of the unidentified fungus was enhanced by small amounts $(0.25,0.5$, and $0.75 \mathrm{~mL})$ of oxalic acid and inhibited by higher concentrations (1.0 and $2.0 \mathrm{~mL}$ ) of the agent. This is supported by observations that some fungal species produce small amounts of oxalic acids themselves (Lapeyrie 1988).

We observed long-term effects of formic acid and oxalic acid on larvae and adults, but these would not be sufficient for effective control. Although formic acid reduced the magnitude of reproduction significantly, the remaining offspring could still cause considerable damage to the beehive. As the effect of oxalic acid on oviposition was less than for formic acid, the damage that future larvae would cause in this scenario is likely to be more severe. Neither formic nor oxalic acid significantly decreased the rate of successful pupation, so the hatching adult SHBs would remain a severe threat to other colonies.

\subsection{Field experiments}

The promising effects in the laboratory trials could not be achieved in the field experiments, regardless of the tested developmental stage of SHB (adult, eggs, or young larvae). This might be due to different factors. For example, in the laboratory, the beetles were exposed to the agents without any hiding places. In contrast, eggs laid in crevices or in capped brood cells (Ellis et al. 2003; Neumann and Elzen 2004; Spiewok et al. 2007), as well as larvae that mine within combs (Lundie 1940; Schmolke 1974), are likely to be less exposed to the treatments. A high portion $(>50 \%)$ of the introduced adult SHBs could not be relocated in the colonies neither in longer-term trials (e.g., 13 days in the formic acid investigation) nor in shorter trials (e.g., $48 \mathrm{~h}$ in the oxalic acid investigation). However, this could not be attributed to the application of the treatments, as the same result was recorded in the controls. We therefore assume that one or more of the following factors may have been responsible for these results. Neumann and Hoffmann (2008) showed that not all beetles will be collected in a survey using an aspirator on all frames and hive parts. After a 5-day treatment, they killed the colony and dissected all hive parts, and they found $14.06 \pm 10.53 \%$ additional adults. However, this number is much lower than the proportion of missing adults in our study. Another explanation might be the high mobility of adult SHB (Spiewok et al. 2008). SHB adults may have left the apiary during the experiment since they were not recollected in any of the test colonies. Alternatively, dead beetles may have been removed from the unscreened tin foil pans and carried outside of the hive by worker bees. This might be prevented by using screen bottom boards in future experiments. Furthermore, we observed considerable numbers of live adults under the sponge tissues, probably using the devices as a hiding place despite the presence of formic acid. In two out of ten treated hives and in four out of ten controls, female SHBs even laid eggs on the sponge tissues used to evaporate the fluids inside the trays. These observations have led to further investigations of diagnostic trays as in-hive traps for catching SHBs (Buchholz et al. 2009). Finally, we showed that SHBs reproduce on extracted honey combs with pollen cells despite a 7-day treatment with acetic acid that would have been effective against $G$. mellonella. This indicates the requirement of a stringent sanitary policy in honey houses, as already stated by Lundie (1940). In contrast to our study, Schäfer et al. (2009) showed a significant increase of adult SHB mortality in nucleus boxes without bees with a successive $70 \%$ acetic acid treatment (20 $\mathrm{mL}$ for 10 days in the field and another $20 \mathrm{~mL}$ for 5 days at room temperature of $27^{\circ} \mathrm{C}$ ). We assume that the smaller volume of nucleus 
boxes (compared to the regular single Langstroth box in the current study) might have resulted in higher aerial acetic acid concentration. In addition, Schäfer et al. (2009) exposed the adult beetles to more and higherconcentrated acid for a longer period compared to our study, which might have also resulted in the increased SHB mortality.

In conclusion, our data suggest that thymol and most of the organic acids applied are unsuitable controls of SHB. However, we recommend conducting further experiments with acetic acid using high concentrations, long exposure times, and combs in stacked Langstroth boxes.

\section{ACKNOWLEDGEMENTS}

We are grateful to HR Hepburn and MP Hill (Department of Zoology and Entomology, Rhodes University) for providing laboratory facilities. We appreciate the constructive comments of two anonymous referees on an earlier version of the manuscript. Financial support was granted to PN by the German Federal Ministry for Food, Agriculture and Consumer Protection through the Federal Agency for Agriculture and Food.

Acides organiques et thymol: inappropriés comme moyens de lutte alternatifs contre Aethina tumida (Coleoptera: Nitidulidae)?

Apis mellifera / acide formique / acide lactique / acide oxalique / lutte intégrée / petit coléoptère des ruches

\section{Zusammenfassung - Organische Säuren und Thy-} mol: Ungeeignet als alternative Kontrolle von Aethina tumida (Coleoptera: Nitidulidae)? Der Kleine Beutenkäfer, Aethina tumida, ist ein ernstzunehmender Schädling der westlichen Honigbiene, Apis mellifera, dessen Bekämpfung sich im Bienenstock als schwierig herausgestellt hat. Im Labor testeten wir verschiedene Konzentrationen organischer Substanzen (Ameisen-, Milch- und Oxalsäure sowie Thymol), die in Europa zur Kontrolle der parasitären Milbe, Varroa destructor, verwendet werden. Zudem verwendeten wir Essigsäure, ein Wirkstoff, der den Befall gelagerter Honigwaben mit der großen Wachsmotte, Galleria mellonella, abwehrt. Im Vergleich zu den Kontrollen resultierten die Ameisensäure-Konzentrationen von 0,5 $\mathrm{mL}$ (Eier), $0,75 \mathrm{~mL}$ (Wanderlarven) und 2,0 $\mathrm{mL}$ (erwachsene Käfer) in signifikant höheren Mortalitäten (Table I). Gleiche Ergebnisse erzielten wir für Käfer und Wanderlarven bei der Verwendung von Oxalsäure (Table II). Daher wurden diese beiden Substanzen für weitere Feldversuche ausgewählt. Milchsäure (Table I) und Thymol (Table II) wurden aufgrund ihrer geringen Wirkung gegen den Käfer nicht weiter untersucht.

In Experimenten an Bienenstöcken mit einem kontrollierten Befall mit dem Kleinen Beutenkäfer (Figure 2), wurde der Effekt von Ameisen- und Oxalsäure auf drei Lebensstadien des Schädlings (Eier, junge Larven und erwachsene Käfer) getestet. Zur Applikation der Substanzen verwendeten wir Methoden, die in Europa zur Bekämpfung von $V$. destructor eingesetzt werden. Weder das Verdunsten von Ameisensäure mit der Nassenheider ${ }^{\circledR}$ Apparatur über 13 Tage, noch eine Übernacht-Behandlung mit Schwammtüchern auf Diagnoserahmen (Schwammtuchmethode) ergab einen signifikanten Anstieg der Mortalitäten des Schädlings. Gleiche Ergebnisse erzielten wir 24 und $48 \mathrm{~h}$ nach einer Oxalsäure Behandlung mit dem Varrox ${ }^{\circledR}$-Verdampfer (mit 2,5 min Hitze und 15 min Einwirkungszeit).

Wir vermuten, dass die erwachsenen Käfer der Behandlung ausgewichen sind, indem sie sich an Orte im Bienenstock zurückgezogen haben, an denen die Konzentration der Wirkstoffe niedrig war. Oder sie haben den Bienenstock einfach verlassen. Letzteres bestätigt unsere Beobachtung, dass weniger Käfer wiedergefunden wurden, je länger die Dauer des Experiments währte (Table IV). Außerdem könnten tote erwachsene Käfer durch Arbeitsbienen aus dem Stock entfernt worden sein. Ein weiterer Grund für die niedrigen Schädlingsmortalitäten könnte eine zu geringe Konzentration von Ameisenund Oxalsäure gewesen sein. Allerdings würden höhere Dosen wahrscheinlich schädliche Effekte auf das Bienenvolk hervorrufen (z.B. den Verlust der Königin oder Brutschäden).

Nachdem erwachsene Beutenkäfer einer siebentägigen Essigsäurebehandlung auf geschleuderten Honigwaben ausgesetzt waren, konnten keine signifikanten Unterschiede in der Mortalität zwischen Behandlung und Kontrolle festgestellt werden.

Zusammengefasst kann keine der untersuchten Methoden für die Kontrolle auch nur eines Lebensstadiums des Kleinen Beutenkäfers empfohlen werden, 
unabhängig ihrer Effektivität gegen $V$. destructor. Basierend auf unseren Ergebnissen empfehlen wir weitere Experimente mit Essigsäure. Dabei sollten höhere Konzentrationen und längere Behandlungszeiträume untersucht werden, um die Effizienz der Säure als Schutz vor einem Befall gelagerter Waben mit dem Kleinen Beutenkäfer zu evaluieren

\section{Ameisensäure / Apis mellifera / Kleiner Beutenkäfer / Milchsäure / Oxalsäure / Schädlingsbekämpfung}

\section{REFERENCES}

Abbott, W.S. (1925) A method of computing the effectiveness of an insecticide. J. Econ. Entomol. 18, 265-267

Bogdanov, S., Kilchenmann, V., Imdorf, A. (1998) Acaricide residues in some bee products. J. Apic. Res. 37, 57-67

Bolli, H.K., Bogdanov, S., Imdorf, A., Fluri, P. (1993) Zur Wirkungsweise von Ameisensäure bei Varroa jacobsoni Oud. und der Honigbiene (Apis mellifera L.). Apidologie 24, 51-57

Buchholz, S., Neumann, P., Merkel, K., Hepburn, H.R. (2006) Evaluation of Bacillus thuringiensis Berliner as an alternative control of small hive beetles, Aethina tumida Murray (Coleoptera: Nitidulidae). J. Pest Sci. 79, 251-254

Buchholz, S., Schaefer, M.O., Spiewok, S., Pettis, J. S., Duncan, M., Ritter, W., Spooner-Hart, R., Neumann, P. (2008) Alternative food sources of Aethina tumida (Coleoptera: Nitidulidae). J. Apic. Res. 47, 202-209

Buchholz, S., Merkel, K., Spiewok, S., Pettis, J.S., Duncan, M., Spooner-Hart, R., Ulrichs, C., Ritter, W., Neumann, P. (2009) Alternative control of Aethina tumida Murray (Coleoptera: Nitidulidae) with lime and diatomaceous earth. Apidologie 40, 535-548. doi:10.1051/apido/2009020

Cabanillas, H.E., Elzen, P.J. (2006) Infectivity of entomopathogenic nematodes (Steinernematidae and Heterorhabditidae) against the small hive beetle Aethina tumida (Coleoptera: Nitidulidae). J. Apic. Res. 45, 49-50

Charrière, J.D., Imdorf, A., Kilchenmann, V. (1992) Konzentrationen der Ameisensäure in der Stockluft von Bienenvölkern während der Anwendung gegen Varroa jacobsoni. ADIZ 26(9), 12-16

Eischen, F.A., Westervelt, D., Randall, C. (1999) Does the small hive beetle have alternative food sources? Am. Bee. J. 139, 125

Ellis, J.D. (2005a) Progress towards controlling small hive beetles with IPM: knowing our options. Part I of Two Parts. Am. Bee. J. 145, 115-119
Ellis, J.D. (2005b) Progress towards controlling small hive beetles with IPM: integrated current treatments. Part II of two parts. Am. Bee. J. 145, 207-210

Ellis, J.D., Delaplane, K.S. (2006) The effects of habitat type, ApilifeVAR, and screened bottom boards on small hive beetle (Aethina tumida) entry into honey bee (Apis mellifera) colonies. Am. Bee. J. 146, 537-539

Ellis, J.D., Neumann, P., Hepburn, H.R., Elzen, P.J. (2002) Longevity and reproductive success of Aethina tumida (Coleoptera: Nitidulidae) fed different natural diets. J. Econ. Entomol. 95, 902-907

Ellis, J.D., Hepburn, H.R., Delaplane, K.S., Neumann, P., Elzen, P.J. (2003) The effects of adult small hive beetles, Aethina tumida (Coleoptera: Nitidulidae) on nests and flight activity of Cape and European honeybees. Apidologie 34, 399-408

Ellis, J.D., Rong, I.H., Hill, M.P., Hepburn, H.R., Elzen, P.J. (2004) The susceptibility of small hive beetle (Aethina tumida Murray) pupae to fungal pathogens. Am. Bee. J. 144, 486-488

Ellis, J.D., Spiewok, S., Delaplane, K.S., Buchholz, S., Neumann, P., Tedders, W.L. (2010) Susceptibility of Aethina tumida (Coleoptera: Nitidulidae) larvae and pupae to entomopathogenic nematodes. J. Econ. Entomol. 103, 1-9

Elzen, P.J., Westervelt, D. (2002) Detection of Coumaphos resistance in Varroa destructor in Florida. Am. Bee. J. 142, 291-292

Elzen, P.J., Baxter, J.R., Westervelt, D., Randall, C., Delaplane, K.S., Cutts, L., Wilson, W.T. (1999) Field control and biology studies of a new pest species, Aethina tumida Murray (Coleoptera, Nitidulidae), attacking European honey bees in the Western Hemisphere. Apidologie 30, 361-366

Floris, I., Satta, A., Cabras, P., Garau, V.L., Angioni, A. (2004) Comparison between two thymol formulations in the control of Varroa destructor: effectiveness, persistence, and residues. J. Econ. Entomol. 97, 187-191

Gillespie, P., Staples, J., King, C., Fletcher, M.J., Dominiak, B.C. (2003) Small hive beetle, Aethina tumida (Murray) (Coleoptera: Nitidulidae) in New South Wales. Gen. Appl. Entomol. 32, 5-7

Gregorc, A., Pogačnik, A., Bowen, I.D. (2004) Cell death in honeybee (Apis mellifera) larvae treated with oxalic or formic acid. Apidologie 35, 453460

Hoffmann, D., Pettis, J.S., Neumann, P. (2008) Potential host shift of the small hive beetle (Aethina tumida) to bumblebee colonies (Bombus impatiens). Insect. Soc. 55, 153-162

Hood, W.M. (2000) Overview of the small hive beetle Aethina tumida in North America. Bee. World 81, 129-137

Hood, W.M. (2004) The small hive beetle Aethina tumida: a review. Bee. World 85, 51-59

Hood, W.M., Miller, A.G. (2003) Trapping small hive beetles (Coleoptera: Nitidulidae) inside colonies of 
honey bees (Hymenoptera: Apidae). Am. Bee. J. 143, 405-409

Imdorf, A. (2005) Konzentrationen in der Luft nach der Anwendung verschiedener Dosierungen von Ameisen-, Essigsäure und Thymol zur Bekämpfung des Kleinen Beutenkäfers (Aethina tumida, Murray; Coloptera: Nitidulidae). ALP Intern. 35, $1-7$

Imdorf, A., Kilchenmann, V. (1990) Milchsäure - ein Varroabekämpfungsmittel für den Kleinimker, Schweiz. Bienenztg 113, 441-443

Imdorf, A., Kilchenmann, V., Bogdanov, S., Bachofen, B., Beretta, C. (1995) Toxizität von Thymol, Campher, Menthol und Eucalyptol auf Varroa jacobsoni (Oud.) und Apis mellifera L. im Labortest. Apidologie 26, 27-31

Imdorf, A., Bogdanov, S., Ochoa, R.I., Calderone, N.W. (1999) Use of essential oils for the control of Varroa jacobsoni (Oud.) in honey bee colonies. Apidologie 30, 209-228

Kochansky, J., Wilzer, K., Feldlaufer, M. (2001) Comparison of the transfer of coumaphos from beeswax into syrup and honey. Apidologie 32, 119-125

Lapeyrie, F. (1988) Oxalate synthesis from soil bicarbonate by the mycorrhizal fungus Paxillus involutus. Plant Soil 110, 3-8

Leichnitz, K. (1985) Prüfröhrchen Taschenbuch. 6. Ausgabe Drägerwerk AG, Lübeck

Lundie, A.E. (1940) The small hive beetle Aethina tumida. Science Bulletin 220, Dep. Agr. Forestry, Government Printer, Pretoria, South Africa

Moosbeckhofer, R. (1993) Wachsmotten - eine Gefahr für den Wabenvorrat. Bienenvater 6, 261-270

Mostafa, A.M., Williams, R.N. (2000) New record of the small hive beetle in Egypt and notes on its distribution and control. Bee. World 83, 99-108

Mürrle, T.M., Neumann, P. (2004) Mass production of small hive beetles (Aethina tumida Murray, Coleoptera: Nitidulidae). J. Apic. Res. 43, 144145

Mürrle, T.M., Neumann, P., Dames, J.F., Hepburn, H.R., Hill, M.P. (2006) Susceptibility of adult Aethina tumida (Coleoptera: Nitidulidae) to entomopathogenic fungi. J. Econ. Entomol. 99, 1-6

Mutinelli, F., Baggio, A. (2004) Use of drugs against varroosis. APIACTA 39, 53-62

Neumann, P., Elzen, P.J. (2004) The biology of the small hive beetle (Aethina tumida Murray, Coleoptera: Nitidulidae): gaps in our knowledge of an invasive species. Apidologie 35, 229-247
Neumann, P., Härtel, S. (2004) Removal of small hive beetle (Aethina tumida) eggs and larvae by African honeybee colonies (Apis mellifera scutellata). Apidologie 35, 31-36

Neumann, P., Hoffmann, D. (2008) Small hive beetle diagnosis and control in naturally infested honeybee colonies using bottom board traps and CheckMite + strips. J. Pest Sci. 81, 43-48

Pettis, J.S. (2003) A scientific note on Varroa destructor resistance to coumaphos in the United States. Apidologie 35, 91-92

Przewozny, A., Zautke, F., Bienefeld, K. (2003) Tierquälerei oder sinnvolles Medikament? Neue Erkenntnisse zur Auswirkung der Ameisensäurebehandlung auf das Verhalten der Bienen, Dtsch. Bienenj 8, 318-319

Rademacher, E., Harz, M. (2006) Oxalic acid for the control of varroosis in honey bee colonies-a review. Apidologie 37, 98-120

Rademacher, E., Brückner, D., Otten, C., Radtke, J. (1999) Varroatosebekämpfung mit Ameisensäure im Applikator bei unterschiedlichen Betriebsweisen und Standortbedingungen, Dtsch. Bienenj 9, 4-7

Schäfer, M.O., Ritter, W., Pettis, J.S., Teal, P.E.A., Neumann, P. (2009) Effects of organic acid treatments on small hive beetles, Aethina tumida, and the associated yeast Kodamaea ohmeri. J. Pest Sci. 82, 283-287

Schmolke, M.D. (1974) A study of Aethina tumida: the small hive beetle. Project report, University of Rhodesia

Spiewok, S., Neumann, P. (2006) Cryptic low level reproduction of small hive beetles in honeybee colonies. J. Apic. Res. 45, 47-48

Spiewok, S., Pettis, J.S., Duncan, M., Spooner-Hart, R., Westervelt, D., Neumann, P. (2007) Small hive beetle, Aethina tumida, populations I: infestation levels of honeybee colonies, apiaries and regions. Apidologie 38, 595-605

Spiewok, S., Duncan, M., Spooner-Hart, R., Pettis, J.S., Neumann, P. (2008) Small hive beetle Aethina tumida, populations II: dispersal of small hive beetles. Apidologie 39, 683-693

Spreafico, M., Eördegh, F.R., Bernadinelli, I., Colombo, M. (2001) First detection of strains of Varroa destructor resistant to coumaphos. Results of laboratory tests and field trials. Apidologie 32, 49-55

Wallner, K. (1999) Varroacides and their residues in bee products. Apidologie 30, 235-248 